Click www.researchjournal.co.in/online/subdetail.html to purchase.

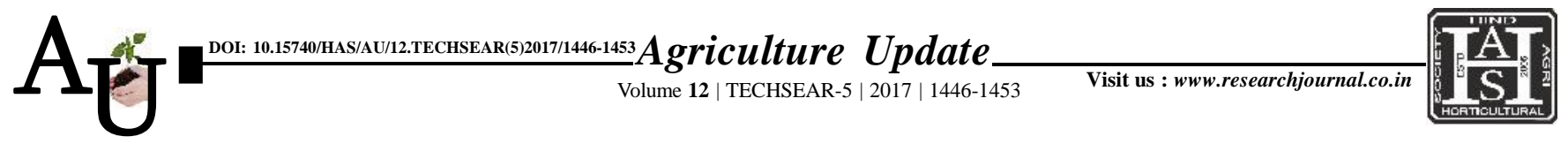

\title{
Research article: Bio-efficacy of new insecticides against the management of leaf folder, Cnaphalocrocis medinalis (Guenee) (Lepidoptera: Pyralidae) in rice
}

B.K. VANITHA, C.T. ASHOK KUMAR AND L. VIJAY KUMAR

Article Chronicle: Received : 15.07.2017;

Accepted : 30.07.2017

KEY WoRds:

Rice, Rice leaf folder, Acephate,

Chlorantanili prole
SUMMARY : Studies on the different chemicals evaluated for their bio-efficacy against rice leaf folder revealed that, acephate $75 \mathrm{SP} @ 675 \mathrm{~g}_{\text {a.i ha }}{ }^{-1}$ (92.30\% reduction with 0.14 larvae/ hill) followed by chlorantaniliprole $18.5 \mathrm{SC} @ 41.62 \mathrm{ml}$ a.i. ha ${ }^{-1}$ (91.75\% reduction with 0.15 larvae/ hill), flubendiamide 20 WDG @ $36 \mathrm{~g}$ a.i. ha- ${ }^{-1}$ (90.10\% reduction) and indoxacarb $15.8 \mathrm{EC} @ 35.55 \mathrm{ml}^{\text {a.i. }} \mathrm{ha}^{-1}$ (88.46\% reduction) were found significantly superior in reducing the population of leaf folder larvae.Among the insecticides evaluated against per cent leaf damage, the lowest leaf damage was recorded in acephate 75 SP @ 675 g a.i ha ${ }^{-1}$ (63.15\% reduction with $5.74 \%$ leaf damage), flubendiamide 20 WDG @ $36 \mathrm{~g}^{2}$.i. ha ${ }^{-1}$ (62.19\% reduction with $5.89 \%$ leaf damage), chlorantaniliprole $18.5 \mathrm{SC} @ 41.62 \mathrm{ml}$ a.i. ha ${ }^{-1}$ (61.36\% reduction) and indoxacarb $15.8 \mathrm{EC} @ 35.55 \mathrm{ml}$ a.i. ha ${ }^{-1}$ (60.78\% reduction); besides recorded higher grain and fodder yield compared to rest of the treatments.Acephate $75 \mathrm{SP} @ 675 \mathrm{~g} \mathrm{a.i} \mathrm{ha}^{-1}$ was found to be the best insecticide in getting highest net profit and cost benefit ratio with lower leaf folder infestation (Rs. 64,264, 1: 2.79). Other insecticides such as indoxacarb $15.8 \mathrm{EC} @ 35.55 \mathrm{ml}$ a.i. ha ${ }^{-1}$ (Rs. 62,037, 1: 2.65), flubendiamide 20WDG @ $36 \mathrm{~g}$ a.i. ha ${ }^{-1}$ (Rs.62,307,1:2.64) chlorantaniliprole 18.5 SC @ $41.62 \mathrm{ml}$ a.i. ha ${ }^{1}$ (Rs. 63,761, 1: 2.55), indoxacarb 14.5 SC @ $39.15 \mathrm{ml}$ a.i. ha ${ }^{-1}$ (Rs. 54, 642, 1:2.31) and spinosad 45 SC @ $48.60 \mathrm{ml}$ a.i. $\mathrm{ha}^{-1}(55,103,1: 2.28)$ were also recorded better cost benefit ratio and net profit.

How to cite this article : Vanitha, B.K., Ashok Kumar, C.T. and Vijay Kumar, L. (2017). Bio-efficacy of new insecticides against the management of leaf folder, Cnaphalocrocis medinalis (Guenee) (Lepidoptera: Pyralidae) in rice. Agric. Update, 12(TECHSEAR-5) : 1446-1453; DOI: 10.15740/HAS/AU/12.TECHSEAR(5)2017/14461453.
Author for correspondence :

\section{B.K. VANITHA}

Department of

Agricultural

Entomology, University of Agricultural Sciences, G.K.V.K., BENGALURU (KARNATAKA) INDIA

See end of the article for authors' affiliations 